Bucureşti

\title{
METALS, WORDS AND GODS. EARLY KNOWLEDGE OF METALLURGICAL SKILLS IN EUROPE, AND REFLECTIONS IN TERMINOLOGY
}

\section{PRELIMINARIES}

How can metallurgical terminology - specifically names of metals - support archaeological investigation? Can comparative linguistics and archaeology co-operate in order to identify the emergence and development of metallurgical skills? How did Neolithic and Bronze Age man imagine the taming of nature in order to achieve metal artifacts?

Such questions - and many others - may arise whenever we try to investigate the beginnings and making of civilization. It is clear that the various aspects connected to archaeometallurgy cannot be analyzed separately from other aspects of human life, like agriculture, trade, urbanization, religious beliefs, early writing systems, pottery techniques, a.o. The earliest known (or identifiable) names of metals do reflect a certain ideology and a certain way of 'seeing' metals as imbued with magic powers. It is certain that colours and reflections - specific to metals - made early man interpret them as divine (Biek and Bayley 1979; Muşu 1981, chapter Symphony of colours, a first attempt in reconstructing pre-Greek names of colours).

We can now accept that Neolithic Europe - with all its specific cultural achieve-

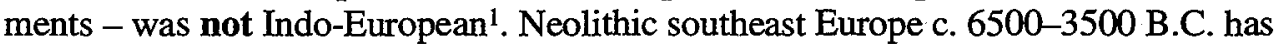
been termed by Marija Gimbutas 'Old Europe', and this term might be used in order to define this vast cultural bloc: a matrifocal, matrilinear and equalitarian society whose people created a wonderful pottery and did not use sharp weapons for war purposes but for hunting and wood-cutting. They also used - at a certain stage of development - a sacral writing system, probably locally developed from Late Palaeolithic/Mesolithic sacred signs and symbols (Gimbutas 1973 a; 1982; n.d.; Winn 1981). The survival of 'Old European' ideology has also been convincingly explained (Gimbutas 1986) and is supported by numerous linguistic data (e.g. Alessio 1935; 1955; Gerola 1942; Paliga 1987, 1989; Ribezzo 1950; Rostaing 1950). Our analysis should therefore concentrate on the question whether words (terms) of possibly pre-Indo-Eu-

1 Unfortunately in no way can the present author subscribe to the hypothesis advocated by Colin Renfrew in his recent Archaeology and language, London: J. Cape 1987. For the justified observations concerning this book see e.g. M. Gimbutas's review in Current Anthropology June 1988 (in print when this paper is being prepared). 
ropean (hereafter pre-IE) origin have been preserved down to historical times, even until modern times. As a good example, it should be observed that only about $40 \%$ of the vocabulary of Greek can be attributed to the Indo-European (hereafter IE) heritage (Chantraine 1968-1980: IX: "Mais aussi de nombreux vocables dont nous ignorons l'origine sont des termes d'emprunt et que l'on désigne souvent par les termes d'égéen ou de 'méediterranéen' qui dissimulent pudiquement notre ignorance"). Despite the (probably) largely spread opinion that the pre-IE heritage is far too difficult to be investigated, present author's view is that this heritage is surprisingly high and associated with the IE heritage; the analysis is not only possible but now even inevitable.

Of course, such an analysis can be profitably extended to the whole European area or to any area where the distinction IE $v$. pre-IE can be made. It is pointless to await miraculous solutions to such complex aspects as the pre-IE heritage; such solutions do not exist. We are not very far from the moment when tens, maybe hundreds, of pre-IE terms have been properly listed and analyzed in a coherent way, something like the way in which primitive IE roots have been analyzed. Indeed, what we need is perhaps more coherence in working with the 'pre-IE phenomenon'.

In the light of these preliminary data, the purpose of this paper is to analyze the origin and distribution of some essential names of metals, mainly in European languages, beginning with the names of earliest known metals - copper and gold - and continuing with the names for bronze and iron. In our view there still are unobserved (or not properly interpreted) data; it is not therefore our purpose just to summarize or up-date already known facts as stated mainly in two fundamental studies dedicated to names of metals: the older one of Paul Kretschmer (1952) and the newer one of V.V. Ivanov (1983). The importance of the Dii Fabri - gods supervising metallurgical activities - will be briefly pointed out at the end.

\section{COPPER, GOLD, LEAD}

In the 1930's it already became clear that important metallurgical terms of the Aegean civilization should be accepted as pre-Greek, i.e. inherited from the Mediterranean substratum. Such words were $\chi \alpha \lambda$ кós 'copper', later also 'bronze',

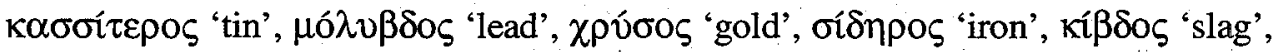
$\lambda \varepsilon ́ \beta \eta \zeta$ 'cauldron' (Glotz 1937: 441). Though their pre-IE origin was sometimes doubted (see further discussions and references in Frisk $1960 \mathrm{ff}$. and Chantraine 1968-1980, s.v.) there can be little doubt that these forms really reflect a pre-IE heritage. Doubts have persisted (and will surely persist) because we still lack a reasonable definition of what Old European (Gimbutas's term), pre-IE, pre-Greek mean, and what the relations between these terms are. Given the limited scope of this paper I shall focus not on generalities but on some particular details. Indeed for a word like $l e ́ b \bar{e} s$, already quoted, it is even possible to identify the pre-IE root: ${ }^{*} L-B-/ * L-P$ 'stone, rock', one of the first to be analyzed in this perspective (Trombetti 1925: 33 
and 36; Paliga 1987: 25). The eymological analysis shows that pre-historic cauldrons were initially made of stone, probably naturally concave stone slabs. This term is clearly related to an important number of place-names (hereafter PN), undoubtedly of pre-IE origin, spread over a large area in southeast and south Europe. I shall revert to the situation of Gr. kíbdos below, in a quite unexpected context.

Three terms are also relevant for the pre-IE perspective - the names for 'copper', 'gold', and 'lead'. The etymological analysis is impeded, though it is not a locus desperatus, by the very fact that we know very little (if anything) about the phonetic structure of the substrate (pre-IE) idioms of southeast Europe.

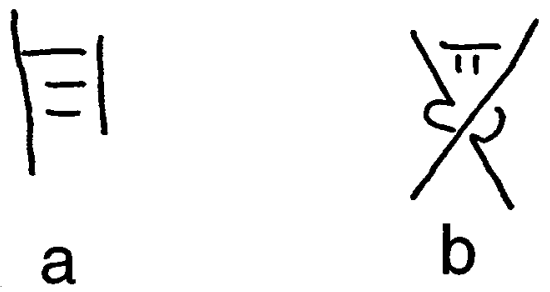

Fig.1 Mycaenean symbols for (a) bronze and (b) gold. (After Morpurgo 1963: XXIX).

Gr. khalkós (Mycaenean ka-ko, cf. Morpurgo 1963: 125) cannot be surely explained as an IE heritage (as formerly done, cf. Kretschmer 1952). Equally I do not find it useful (or correct) to hypothesize an Oriental origin (Chantraine 1968-1980: 1244). But to invoke IE or Oriental heritage is for many scholars preferable because we deal with known (or, at least, better known) facts. Archaeological finds document an old indigenous copper metallurgy in SE Europe (Comşa 1987: 102 ff.; Gimbutas 1973a,b; Cernyh 1976: 17) and it is therefore feasible that Neolithic man of SE Europe had no need to borrow (when and how?) a term denoting a metal he had known from immemorial times. Some similar terms spread in the Aegean and Mediterranean may be due to the existence in pre-history of an archaic pre-IE/pre-Semitic substratum which could have included similar terms. It is also feasible to suppose that even those languages had similar (or even identical?) structures.

If we really try to find a closely related word to khalkós, then this might be, among others, the ethnikon Xó $\lambda v \beta \varepsilon \zeta$, a group of the south part of Pontus (Chantraine, ibidem). If placed in this pre-IE context, it is even possible to suggest a pre-IE root, identified as such a long time ago: ${ }^{*} K(h) a L-$, also ${ }^{*} K(h) a R(r)$ - 'stone, cliff hill, mountain'. The spelling (aspirated $k$ ) should not impede an approach to other forms spelled without aspiration (Trombetti 1925: 28; Alessio 1935; Rostaing 1950: 117). A whole series of place-names could be quoted in this context, e.g. Callatis, Calabria, Calais, etc. (Kiss 1980). We meet again the parallel term - place-names upon which I drew attention recently following previous observations (Paliga 1987; Trombetti 1925; Rostaing 1950; Muşu 1981). In this perspective, one of the oldest names for 'copper', as attested in Greak, was initiallly associated with mountainous areas, i.e. areas where this metal was found in native form. 

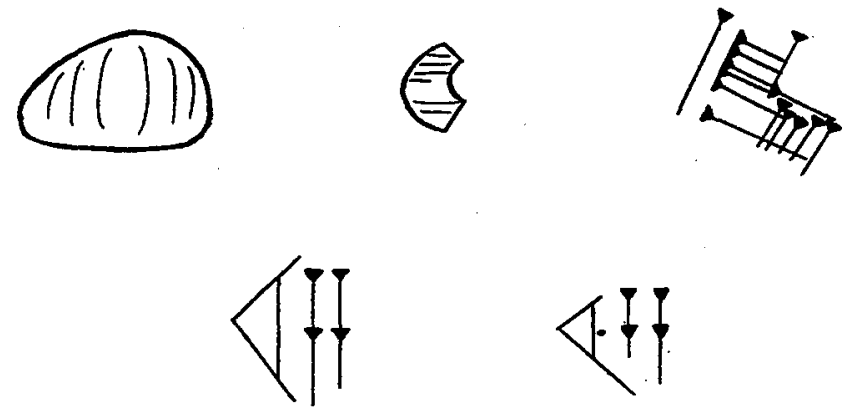

a
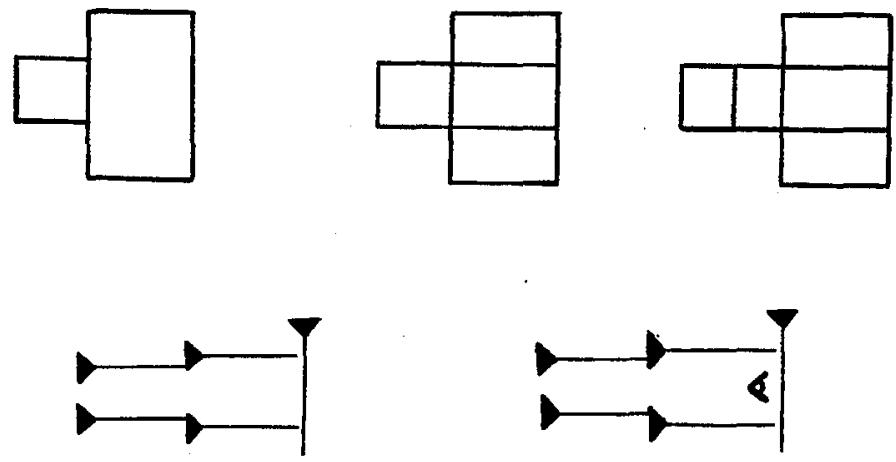

b
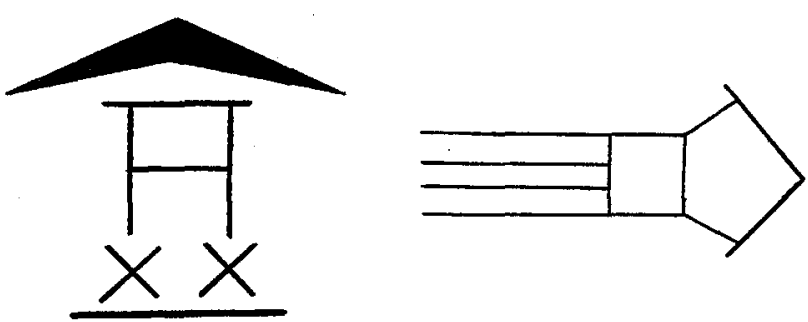

C

Fig. 2 Graphemes for 'metal' in the Middle East:

a) $1.10^{\text {th }}-5^{\text {th }}$ mill. B.C.; 2. Sumerian pictogram; 3. New Sumerian - Old Babylonian; 4. Assyrian; 5. Babylonian.

b) The evolution of Sumerian grapheme for 'copper': URUDU < *BURUDU.

c) Sumerian signs for 'furnace' (GIR4) and 'smith'. (After Limet 1960 and Ivanov 1983). 
It is usually admited that Gr. khrysós 'gold' (Myc. ku-ru-so, cf. Morpurgo 1963: 171) reflects a Semitic influence (Chantraine 1968-1980: 1278 with reference to Masson, E. 1967: 37-38), the probable source being Phoenician hrs (Akkadian hurāsău, Ugaritic h̆rs, Hebrew hārus). From reasons which cannot be developed here, I am inclined to consider this word inherited from the indigenous pre-IE substratum with correspondences in the pre-Semitic substratum. This term could be also named 'Mediterranean'. Many scholars would probably reject such a view because we face a radical question: was there a Mediterranean substratum common to such a vast area covering historical Semitic and SE European territories? The answer seems to be positive, but this is too complex a question to be answered in this paper. In my view, it is even possible to suggest a pre-IE root for the Greek term: ${ }^{*} K-R(r)-{ }^{*}(K a R-$, $\left.{ }^{*} K o R-,{ }^{*} K u R-\right)$, with a parallel $* K-L_{-} *(K a L-)$, and with the reconstructed meaning 'stone, rock, mountain' (Trombetti 1925: 31-33; Rostaing 1950: 138 ff.; Paliga 1989). PN like Kárpatos (island in the Aegean) or the Carpathians (Rom. Carpati) are typical examples for this context. (It should be remembered that rich gold bearing ores have been exploited in the Carpathians from immemorial times). In explaining Gr. khrysós we should start either from an initial form $* K u R-u s$ - or from an initial zero-grade form ${ }^{*} K R$-us-. Mycaenean kuruso does not necessarily imply that the first variant is the only possible, because in a syllabary the combination consonant + consonant cannot be accurately spelled. Zero-grade parallel forms of this root are well documented in place-names (cf. Rostaing 1950: $153 \mathrm{ff}$.). If this interpretation is accepted, the implication is immediate: the Greek name for 'gold' is also connected with archaic roots denoting mountainous areas where this metal was exploited. This detail is confirmed not only by logic or linguistic analysis but by archaeological evidence as well (cf. Černyh 1976).

Gr. mólybdos 'lead' ( also spelled mólibdos, mólibos, Myc. moriwodo, i.e. *moriwdo, cf. Morpurgo 1963: 192-3) is one of the terms for which a non-IE origin has been lately accepted, being analyzed in connection with Lat. plumbum 'lead'. There are discussions of the type: in which way should we understand the alleged relationship between mólybdos, mólib(d)os, and plumbum? There are some possible answers like (1) " Eine Entlehung aus einer nicht näher bestimmbaren mittelmeerländischibe-

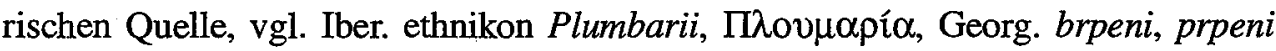
'Blei, Zinn', Bask berún 'Blei "(Walde-Hofmann 1938-1954: 325-6), or (2)" terme emprunté, aux formes variées, ce qui n’étonne pas pour un nom de métal. /.../ En général, on pense que le mot est un emprunt parallèle à lat. plumbum et que les deux termes viendraient de l'ibère" (Chantraine 1968-1980: 710), or (3) speaking about Lat. plumbum, that it is a " noun borrowed from the same unidentified source as Greek mólybdos" (AHD 1535). The analysis is difficult because of the divergent forms in Greek and Latin. Yet for Greek it can be surmised that we can refer to a basic form mólybdos, mólib(d)os, therefore a pre-IE root *MoL-, whereas parallels like bólybdos, bólimos are corrupt; but this happens often with many pre-Greek forms (cf. Faure 1977). Indeed, Lat. plumbum, though indisputably a non-IE term, can hardly be direct- 
ly related to the same root $* M o L-$. I am inclined to see here two different roots, both of pre-IE origin: ${ }^{*} M o L-*(M-L-)$ and $* P-L-\left(* P a L-,{ }^{*} P o L-\right.$, zero-grade form $\left.* P L-\right)$. Both roots are well attested in the pre-IE relics and have been analyzed in this context:

(a) Root ${ }^{*} M a L-, ~{ }^{*} M o L$ - 'hill, mountain' (further examples in Trombetti 1925: 38, with the observation that some forms quoted there do not belong to this root; Rostaing 1950: 202; Paliga 1989). The parallel root *MaR-is also well represented. Still preserved until modern times are Alb. mal 'hill', Rom. mal 'riverside' (<'rocky river-side'). Related place-names are attested over a large area, e.g. Cretan Malla (today Malles), Malea (Laconia and Lesbos), Maluentum (Dacia, cf. PN Malnaş in Transylvania and Rom. mal already mentioned), Iberian malh 'cliff', Basque malkar 'rocky region'.

Gr. mólybdos indicates once more that the term was initially associated with the mountainous regions where this metal had been identified by pre-historic man.

(b) Root *PaL- (also *PaR- and *BaL-/*BaR-) 'mountain, elevation' is one of the best known and most analyzed (Trombetti 1925:43; Rostaing 1950:230 ff.; Faure 1977:141; Paliga 1989). PN Peleia (Caria), Pelarmos (Caria), Pelekas (Misia), Alpine peglia 'hauteur nue et herbeuse' reflect this root.

In this perspective, the Latin name for 'lead' - plumbum - is, once again, connected to a pre-IE root meaning 'elevation, hill, mountain'. Of course, the word should be explained from a zero-grade form ${ }^{*} P L$ - $u m b$ - or from $* P u L-u m b$ - $>* P L$ - $u m b$-. There can be no certainty in such cases as long as we still have no coherent view of the pre-IE heritage and, consequently, of the possible phonetic structure of the pre-IE idioms spoken in Neolithic and Chalcolithic Europe.

Latin proves to be another language with solid links with the pre-IE substratum. From this point of view it is interesting to present the situation of (aes) cyprium, later cuprum 'copper' a term with a large diffusion in many modern languages via Late Latin. What is the origin of this fundamental term? At a first glance the answer is simple and immediate: the word is derived from the name of the island Cyprus, Gr. Kviлpos.There are some other details which can be clarified; for example the relation between (aes) cyprium, cuprum and Sumerian zabar 'copper' (i.e. 'gleaming stone'), Assyrian siparru 'id.' is seemingly fortuitous (Frisk 1960 ff.: Lief. 11, 52). Indeed, it is difficult to derive non-IE terms present in European languages from Asia Minor or Sumer, even if we are sometimes confronted with radical assertions like "le grec $k h r y$ sós est certainement dérivé du terme sémitique, Akk. hururāsu, Heb. ḩārūs, Arab hard" (Limet 1960: 41 ff.). Undoubtedly, metallurgy (just like agriculture) developed earlier in the Orient, but facts rather indicate the diffusion of 'know-how' from step to step together with the preservation of many indigenous terms of pre-metallic age adapted to new techniques. Several such terms are discussed in the present paper and the word for 'copper' in Latin (hence in many European languages) is a good example. If the island of Cyprus gave its name to a certain metal, what can we expect from a deeper etymological analysis? What can be the possible etymon of the place-name Kypros? Can this ultimate linguistic perspective support a better explanation? 
The origin of the PN Kýpros should be looked for outside the IE heritage, from a possible root *KuP-. The perspective opened by this non- $\mathbb{E}$ view is once again promising.

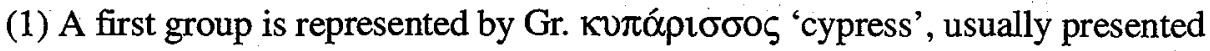
as "terme méditerranéen d'origine inconnue; passé en latin, sous la forme cupressus, peut-être par intermédiaire étrusque "(Chantraine 1968-1980: 600). Though the situation of Lat. cupressus is of secondary importance, it may be surmised that both Greek and Latin inherited - more or less independently - the same term from the substratum. I do not see any need to suppose an Etruscan intermidiary which is too late on the chronological scale. Gr. kypárissos and Lat. cupressus are paralleled by two relevant terms: Albanian kopaç and Romanian copac (dialectally also cupaciu, $c i=\check{c}$ ) 'a tree'. To my knowledge this obvious relationship of Greek, Latin, Albanian and Romanian terms has not been observed (or was simply considered fortuitous?). It can be little doubt that we may here identify a pre-IE heritage: root ${ }^{*} \mathrm{KoP}-,{ }^{*} \mathrm{Ku} \mathrm{P}_{-}$'bush, tree'.

(2) Another group relevant to this topic is represented by the modern form copil 'a child' (in Romanian and Albanian, diffused all over southest Europe). The word is considered indigenous in Romanian (just like copac 'tree'), i.e. of Thracian origin, proved by the clear Albanian parallel. Yet there is an almost identical parallel in the Uralic languages: Selkup kypa 'small, little' (Collinder 1957: 482)2. This unexpected similarity (undoubtedly not a result of hazard) may clarify - in a quite unexpected way - obscure facts. Starting from a minimum of information, we can reconstruct another pre-IE root $* \mathrm{KoP}-,{ }^{*} \mathrm{KuP}$ - 'small, little', in this case pre-Uralic as well. Once this view is accepted, I am inclined to include here unexplained Greek terms like

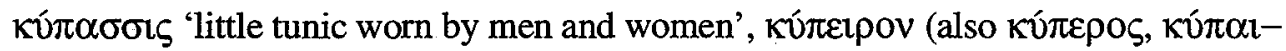
$\rho \circ \varsigma$ ), name of a plant with aromatic roots (name derived from its probable small size), кú $\tau \rho \circ \zeta$, a measure for grain (i.e. 'small measure'). For all these words, present in southeast Europe and even in an Uralic idiom, a primitive root with the meaning 'small, little' may be reconstructed. Two questions may now arise:

(a) What can there be the relation between the two meanings 'bush, tree' and 'small, little'? The answer seems logically easy: it can be supposed that the oldest meaning for the group 'bush, tee' was also 'small', i.e. 'small tree or plant'. Later the two groups became independent (perhaps already in pre-IE times) and the speakers did not feel the initial connection any more.

(b) In what way are all these forms relevant to our problem, the origin of the PN Kýpros, and consequently, the primitive etymon of the term 'copper'?

It should be remembered that the root $* K o B-/ * K o P$ - was discussed in the case of several place-names (Trombetti 1925; Rostaing 1950). It may be of course questioned

2 French copain, derived from compain, in its turn from compagnon, which reflects a Late Latin form *companio, -onis 'someone who eats bread with', is a loan translation (calque) after Gothic ga-hlaiba 'with-bread'. This form has therefore nothing to do with the context discussed. 
whether all these forms really repose on a primitive root with the meaning 'small, little', eventually whether all these forms really have a common origin. In my opinion at least some (if not all) of these forms reflect the preservation of an archaic pre-IE root. The spread of the forms from west to south and southeast Europe is normal as long as many other examples confirm it. The PN Kýpros cannot be any longer considered enigmatic as long as many other parallels can be quoted.

Yet I have not answered the most important question: what is the connection between the primitive meaning 'small, little' and the name Kýpros? Surely, it is not a small island, therefore a primitive meaning 'small island' can be easily rejected. A second hypothesis assumes that the PN is related - in a way or another - to kypárissos 'cypress', mainly because this tree is abundant on the island (Guyot and Gibassier 1960: 33-4). A third possibility - which I support in the context discussed - is that initially the name of the island was derived from something which had had the meaning 'small, little'. This was the primitive pre- $\mathbb{E E}$ name for 'copper'. In other words, an old pre-IE word for 'copper' was associated with the idea of smallness. A key-word for solving this difficult and extremely delicate problem may be Rom. a copleşi 'to press, to squeeze, to overwhelm', i.e. 'to make, turn small', a verb now accepted as probably indigenous, of Thracian origin. ${ }^{3}$ I should add: of pre-Thracian origin, derived from the same root $* \mathrm{KoP}-{ }^{*} K u P$ - 'small, little', i.e. 'to turn small, to squeeze'. In a similar way, a pre-Greek form * KuP-ro- was used to denote the soft metal (copper), literally the 'metal which could be squeezed, hammered into small pieces'.

In the light of the data presented, there are two ways of explaining the Latin name for 'copper':

(1) One possibility is to derive it from the PN Kýpros, in its turn derived from (or related to) kypárissos 'cypress'. Pre-IE root *KoB-/*KoP-/*KuP- 'small, little'> name for 'cypress' (initially 'small plant/ tree') $>$ name of island $>$ name of metal.

(2) The other possibility - to which I incline - may be summarized: pre-IE root ${ }^{*} K o B-/ * K o P-/ * K u P$ - 'small, little'>name for copper ('metal which can be turned small') $>$ name of island (from its copper bearing ores). At a later stage, when the initial pre-IE idiom became extinct, folk-etymology derived the name for 'copper' from the place-name.

It is understandable that it is too early to offer an ideal solution to such obscure facts. The pre-IE heritage is still little and often incoherently analyzed, but future data will surely substantiate many details and consequently clarify this topic as well.

I should point out that this context (the pre-IE root $/ * K-B-/ * K o P$ - 'small, little') can offer a good explanation to another important term noted above: kibdos 'slag'. Indeed, the root of this word seems to be again $* K-B-/ * K-P$-. The primitive meaning

3 Given the limited dimensions of this paper, the author cannot extend discussions concerning the problem of the Thracian heritage in SE Europe. A good introduction for the English reader, with further references, was recently done by $\mathrm{T}$. Taylor (1987). 
of the word seemingly was '(small)particles'. Quite unexpectedly, both kibdos 'slag' and (aes)cyprium, cuprum can be therefore explained as initially deriving from the same pre-IE root. Can this be acceptable? Facts show that the situation really was so. A fascinating history is hidden behind every word if it is unveiled.

Lat. aurum 'gold', from an older form *aus-om, has quite clear parallels: Old Prussian ausis 'id.', Lithuanian auksas 'id.' (with an epenthetic $k$ unexplained), Tokharian A väs 'id.'. The primitive reconstructed root is *aus- and its proto-IE character seems to be proved by the preservation of similar forms on a large area (Ernout and Meillet 1959: 60). Indeed, gold must have been an important metal of the IE society and the search for gold was probably one of the impulses (maybe the most important) to the IE expansion (Gimbutas 1973 a).

\section{BRONZE: AN INDO-EUROPEAN METAL}

The only IE name of metal reconstructable from forms preserved all over the IE area is *ayos: Lat. aes (initially ais) 'bronze', sometimes 'copper' (i.e. 'copper alloy'), Gothic aiz (Gen. aizis), 'ore', Sanskrit áyah (Gen. áyasah), Avestan ayō (Gen. ayanhō), etc. (Pokorny 1959: 15; Morris et al. 1979: 1507; Ivanov 1983: 32; Lehmann 1987: 78). This term places us on the more firm ground of the comparative grammar of the IE languages. This confirms archaeological finds which now indicate that intentionally produced copper alloys were introduced into Europe by the Kurgan People: the Indo-Europeans (Gimbutas 1973 a,b; 1979).

\section{AN UNEXPECTED DIFFICULTY: THE NAME FOR 'IRON'}

The name for 'iron' poses unexpected problems to linguists because in a series of languages it has no accepted or acceptable etymon. Gr. síderos and Lat. ferrum are two typical examples. Both IE and pre-IE perspectives are obscure from the very beginning: the Indo-Europeans did not know or use iron, and the same thing is valid for their indigenous (Neolithic and Chalcolithic) predecessors. The etymological analysis is confronted with a serious problem. If the term is surely non-IE (non-ProtoIndo-European) can it be pre-IE? A positive answer implies a total anachronism whereas a negative answer leads to an even more disconcerting position: where was this term taken from or how was it invented? An authority in Greek etymology rejected a hypothesis which - in the present author's opinion - has good chances to be real: iron was initially known from meteorites. The argument invoked is purely phonetical: the presence of initial $s$ - (Chantraine 1968-1980: 1002-3). But the phonetic treatment of initial $s$ in Greek is clear enough only in the case of the IE heritage. But what can we say about the treatment of initial $s$ in the substratum elements? Tens other examples show that it is highly probable that initial $s$ was preserved in the substratum (pre-IE) terms and, very probably again, in some IE terms which underwent other 
phonetic treatments (e.g. terms possibly borrowed, at a certain historical stage, from neighbouring idioms, like Thracian, Mlyrian, eventually from other languages about which we have no knowledge). In this sense, there is no need to invoke repeatedly that a word like $\Sigma t \lambda \eta v o ́ \varsigma$ 'a silenus, Silenus' was borrowed. It is much more reasonable to assume that it is an archaic indigenous mythological term just like sídēros 'iron'. The inevitable parallel of this word is, in this view, Lat. sidus, -eris 'a star, constellation', for which an IE root (* sweid- 'to shine') has become largely accepted (Pokorny 1959: 1042; AHD 1979: 1544). It should equally be mentioned that the possible relationship between Gr. sídēros and Lat. sidus was (hesitantly) rejected in favour of a relationship between the Greek word and an Old African form si-tari (Bantu kę-talę) 'iron' (Trombetti 1925: 47). If this relation is improbable, the parallel Gr. síderos 'iron' - Lat. sidus 'star' remains probable, or - at least - possible.

Lat. ferrum also poses difficult problems. A common statement may be one like: "Latin ferrum is possibly borrowed (via Etruscan) from the same obscure source as Old English braes 'brass' (AHD 1979: 1515). Such a statement is similarly presented in Ernout and Meillet (1959: 229) where we are further referred to Akkadian parzillu 'iron', Phoenician barzel 'id', "ce qui ne fournit rien de net".

The Germanic word for 'iron' has been reconstructed as *isarno and is usually derived from the IE root *eis- in words denoting passion, e.g. Lat. ira 'anger', Gr. hieros 'filled with the divine', etc. (Pokorny 1959: 299; AHD 1979: 1514). Yet this derivation has been lately doubted with solid arguments and with the conclusion that "the position of the words for iron in the Germanic lexicon as well as phonological and morphological considerations lead us to the conclusion that they are not native, but rather borrowed from a non-Germanic language" (Lehmann 1987: 78; cf. Polomé 1987: 223). Another doubtful point added to the already existing ones relevated in Greek and Latin. What can there be the situation of Germanic *isarno? If we adopt the position that this term does not belong to the IE heritage, then a pre-Germanic/pre-IE origin might be sustained but it is impossible to advance any possible initial meaning. It might have been a name for another metal in 'pre-ferric' west-central Europe or a name of a colour, etc. Yet I think that the derivation from the IE root *eis- is still feasible in the light of the 'meteoric theory'. In other words, the reconstructed sense 'sacred metal' supports very well the hypothesis that the Indo-Europeans could have known iron as a meteoric metal just like other ethnic groups outside the Kurgan (IE) area.

It is therefore a problem open to speculation whether Gr. siderros and Lat. sidus may be assumed of IE or pre-IE origin. There are arguments supporting both opinions with much chance that the form might be pre-IE, from a primitive reconstructable root * $S-D$ - (*SiD-) 'star, constellation; falling star, meteorite'. 

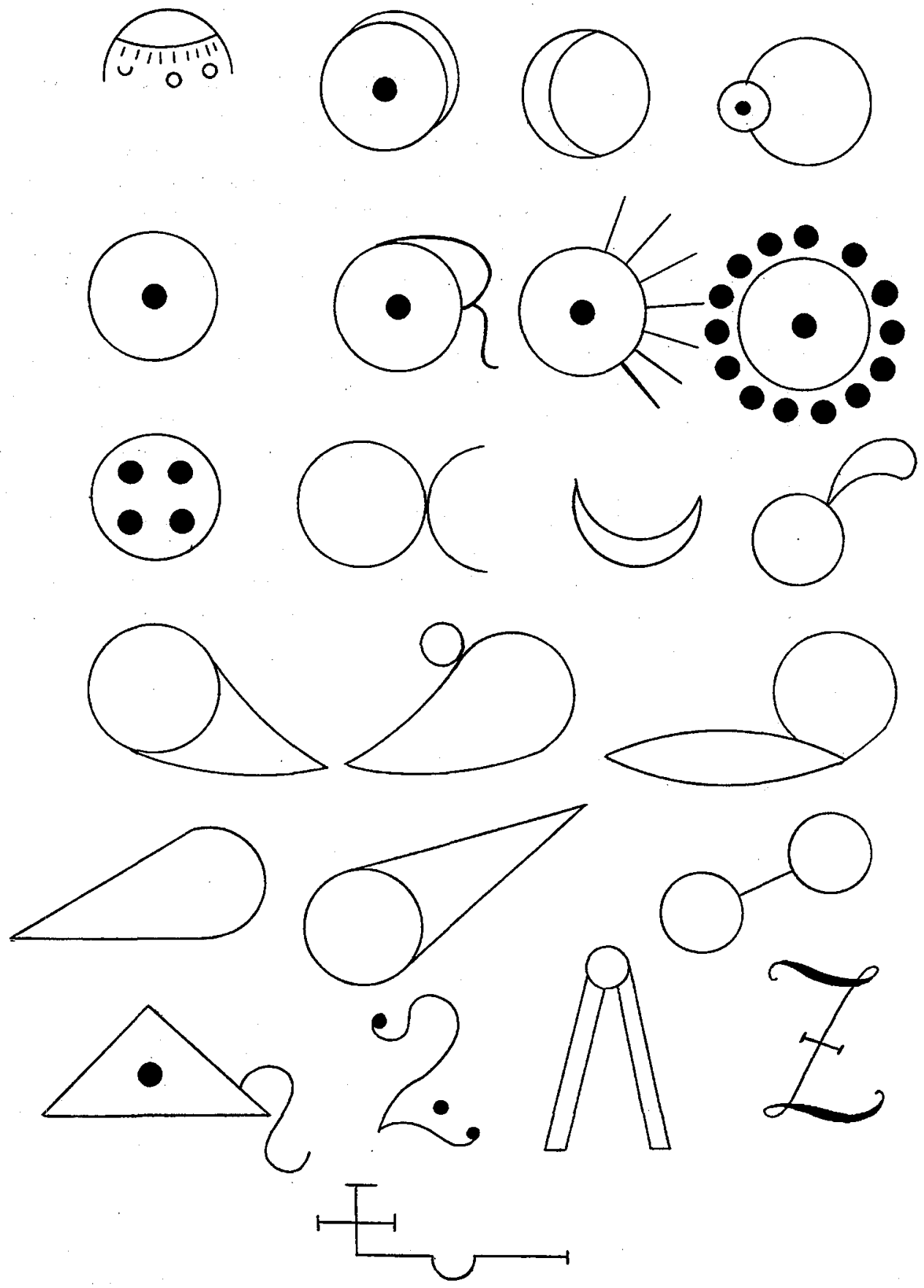

Fig. 3 Alchemic signs for 'gold'. Top left: Egyptian. (After Ivanov 1983 and Junius 1985). 


\section{METALLURGY AND 'L'AU DELA'}

The term metallurgy derived from metal (spread in many European languages) represents Latin metallum, in its turn borrowed from Gr. $\mu$ '́t $\alpha \lambda \lambda \mathrm{ov}^{\prime}$ 'mine', then 'mineral, metal'. This word is obscure as well. Paul Kretschmer, in a classical study dedicated to ancient names of metals, withdrew his previous opinion which had suggested a pre-IE term in connection with a Cretan PN Metallápyton (pyton being obscure); reconsidering this former hypothesis, he suggested an approach to $\mu \varepsilon \tau \alpha \lambda \lambda \alpha \alpha^{\omega} \omega$ 'search after, investigate' (Kretschmer 1952: 1). This hypothesis is appreciated as 'very probable' in Chantraine (1968-1980: 690).

On the other hand, it is clear that a generic name for 'metal' may appear only at a later stage of historical development when man began to process several metals and thus felt the need for such a term. The oldest meaning of Gr. métallon was 'mine' and is clear that initially this word had nothing to do with metallurgy in its broader sense (even if we refer to the level got at in pre-ferric age) but, very probably, with the magic powers of primitive mines which surely had close resemblance with caves and labyrinths. It is therefore more plausible to look for the initial meaning of Gr. métallon in the sphere of magic meanings connected to caves and labyrinths. If this hypothesis is accepted, then métallon should be connected to an arhaic pre-IE root ${ }^{*} M a T(T)$-, *MeT(T)- 'intricate, confuse; maze' (Paliga 1988; the problem of the cult places in the Aegean in analyzed in Rutkowski 1972).

Metallurgical activites were therefore associated with the magic powers of nature as proved not only by the primitive sense of métallon but later by the consciously processed ores which implied high temperatures, i.e. fire. For primitive man this meant the understanding of nature by magic. It should be remembered that the magic virtues of manual work have been preserved until modern times (cf. Benoist 1966). Consequently, the Dii fabri (or smith-gods) had an important role in mythological representations. Comparative mythological analyses show that artisan gods are present in many (perhaps all) mythologies, e.g. Anunnaki and Kothar (Mesopotamia), Twashtri (Vedic mythology), Hephaistos and the secondary figure Technites (from $\tau \varepsilon ́ \chi v \eta$ 'skill, art' akin to lat. texo 'to weave', IE root *teks-), Latin Volcanus/Vulcanus, etc. (Kernbach 1983). A fascinating deus faber is the Finnish god Ilmarinen, a central figure of the Kalevala; this god was initially associated with nature and weather (cf. ilma 'good weather', formerly also 'sky')(Harva 1946). Another interesting figure, still enigmatic, is the Thracian artisan god Dabatopeios. The name seems to be a compound: Dabato-peios, the second part of which is not clear. The first part is yet perfectly analyzable etymologically, reflecting the IE root *dhabh- 'to fit together', hence also Lat. faber (initial $\mathbb{I E} * d h>$ Lat. $f$ ), also modern Romanian form dibaci ( $c i$ $=c$ c) 'skillful', undoubtedly an archaic indigenous term of Thracian origin (Muşu 1982: $139 \mathrm{ff}$.). This theonym is akin to the personal name Dabeis (Dečev 1957: 109). The Thracian artisan god Dabatopeios was a faber or technites par excellence, as 
proved by etymological analysis: a god imagined as the skillful artisan. Another example showing that spiritual achievement was attained by skillful manual work (cf. Benoist 1966; H. Masson 1970). ${ }^{4}$
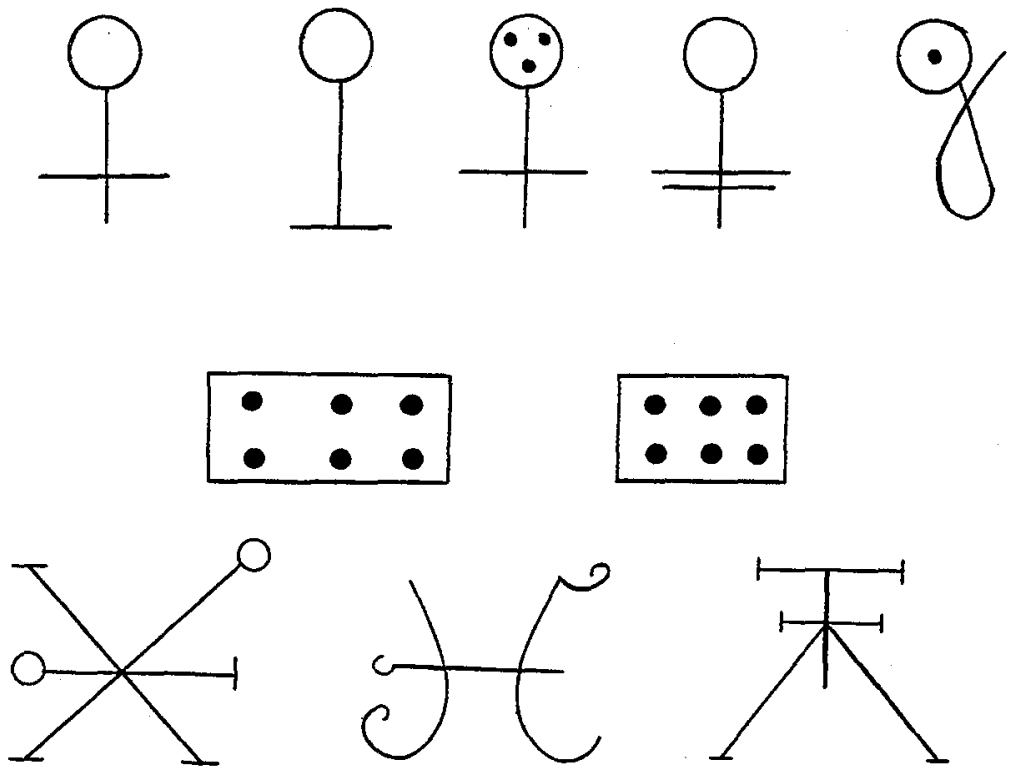

a
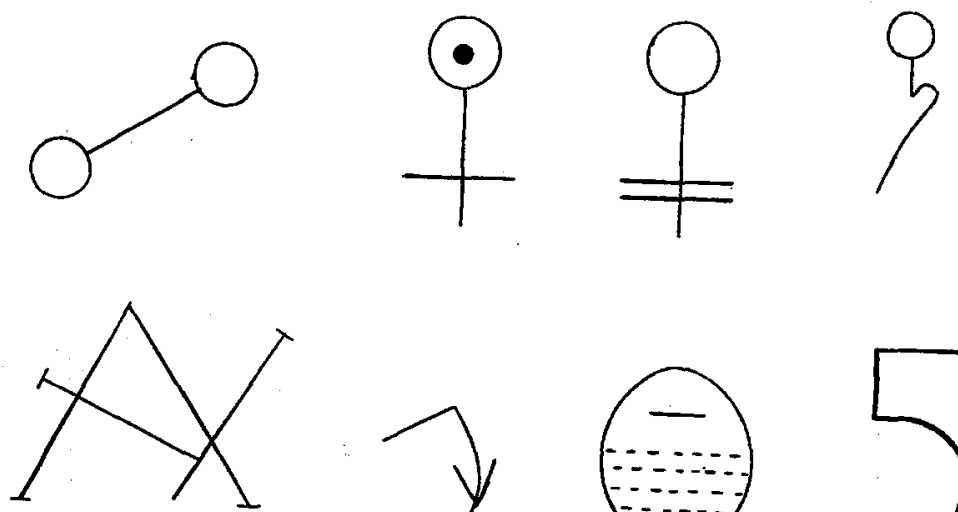

b
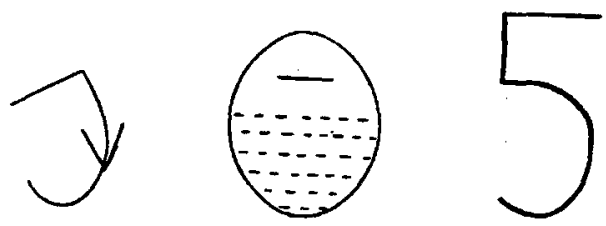

Fig.4 Alchemic signs for 'copper' a) and 'brass' b). (After Junius 1985).

\footnotetext{
4 It should be noted that the first meaning of sophós was 'skillful', later 'clever'. This evolution of meaning may be one of the essential keys to understanding the European spirituality based on homo faber.
} 
In the final part of this study I shall concentrate on two important figures of classical mythology: the Greek lame-god Hephaestus (Hephaistos) and the Latin god Volcanus/Vulcanus. About Hephaestus we cannot unfortunately say much more than at the beginning of this century: "for the time being it is impossible to offer an explanation for god's name" (Malten 1913: 341). The name is, beyond any doubt, of pre-IE origin, like many other words in Greek and like others analyzed in this paper. A major difficulty of analysis consists in the fact that we do not know how to interpret graphic forms of Greek words of pre-IE origin as long as we do not know the phonetic structure of the pre-IE idioms of SE Europe. It would be simplist to assume that the peculiar pre-IE phonemes followed the same phonetic changes like the IE phonemes which can be now fairly well reconstructed by comparative analysis. The point is that only $40 \%$ of the Greek vocabulary admits an IE etymon. The overwhelming majority re-

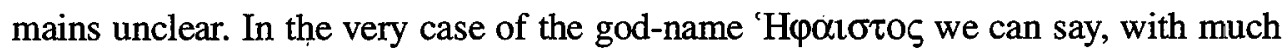
probability, that it must have something in common with the Cretan place-name Phaistos (as already suggested by Malten 1913: 340), with the Mycaenean spelling paito (Morpurgo 1963: 225; Chantraine 1968-1980: 1172). If this is admittedly true, then the name has a structure He-phaistos. Following Gh. Muşu's hypothesis concerning pre-Hellenic heritage, aspirated or non-aspirated vowels in ante-position seem to have the role of a prefix (Muşu 1981). It is clear that if we try to explain peculiar forms it is imperious to abandon the phonetic rules known in the comparative grammars of IE languages. The name of the Greek smith-god Hephaestus has already been analyzed in the light of the pre-IE heritage, unfortunately the study is still unpublished (Muşu n.d.). Nevertheless, Hephaestus's lameness is fairly well interpretable. It should be remembered that lameness appears as a repetitive motive of many ancient and modern mythologies; a lame mythic figure usually represents a god tamed by mutilation. Hephaestus, supervizing the terrible fire of the earth, should have been imagined as lame, i.e. with reduced, not dangerous, powers (Muşu 1972 and personal communication).
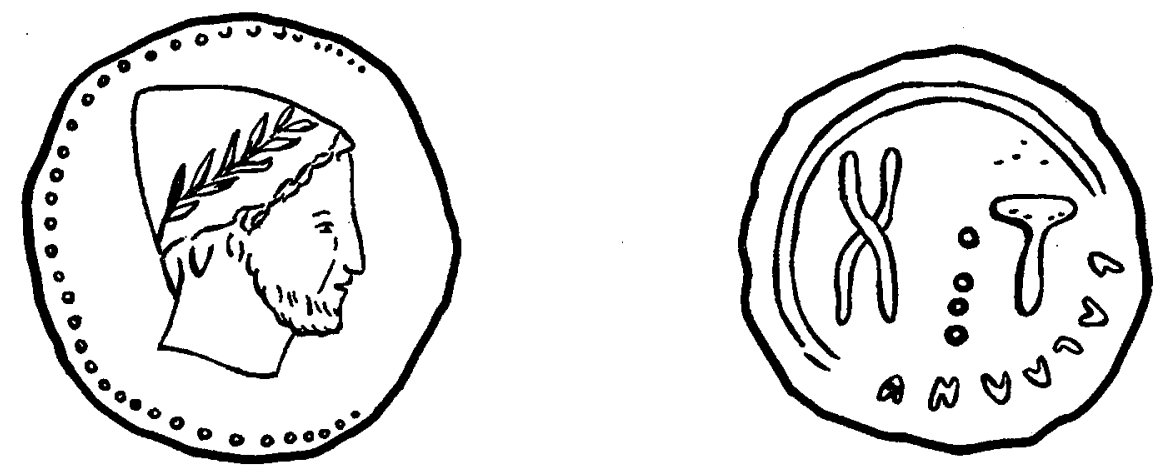

Fig. 5 Sethlans - Etruscan god of smiths and his attributes on a coin found at Populonia. (After Komorovský 1986). 
The etymological analysis of the god-name Volcanus/Vulcanus is, in my opinion, much simpler, despite the common opinion that the name is not analyzable (e.g. Eisenhut 1974: 949). To explain this name is to explain also a detail of spelling: the group $v o-/ v u$ (pronounced $w o-/ w u$ - down to classical age). The name Volcanus/Vulcanus is a good example proving that the root was $* O L-/ * U L$ - 'high, elevated', emphatically pronounced $* W O L-/ * W U L-$; this phenomenon was already analyzed in the case of many pre-IE relics (Rostaing 1950). I see this god-name related to vultur (usually explained as deriving from the IE root * gwltur-, Pokorny 1959: 482 and AHD 1979: 1520) and to many other PN, e.g. Ólympos; Ulcinium, Ulcirus, Ululeus (Illyria); Oloros, Ólynthos (Thracia), Olomouc (Czechia), etc. (further examples in Paliga 1989). Once again we can identify a word of pre-IE origin connected with the mountainous elevations, in this very case with the volcanic mountains.

\section{FINAL REMARKS AND CONCLUSIONS}

The beginnings of metallurgical activities have a particular significance for understanding the civilizational process. This paper concentrated on S and SE Europe, where archaeological finds document the emergence of the earliest European civilization termed 'Old Europe' by M. Gimbutas and 'urbian' by the author of this paper (1989). It is clear that metallurgy is only one aspect of the complex social activities of the Old Europeans. It can be no doubt that metallurgical skills developed in Europe much time before the IE expansion and this is proved not only by archaeological evidence but also by linguistic analysis. Many fundamental terms of earliest documented metallurgical activities are not IE nor can they be attributed to an Oriental influence. Though metallurgy (like agriculture) developed earlier in Anatolia it is little probable that Neolithic and Chalcolithic Europeans imported terms from there. It is anyway unknown whether the pre-IE languages of Anatolia had a similar (or even identical) structure to (with) the pre-IE idioms of SE Europe. This may be very possible as proved by the extraordinary diffusion of many pre-IE terms over a large area. In this perspective it is of course problematic to say who borrowed from where. Several terms analyzed in this paper indicate that the indigenous Europeans rather adapted local realities to new socio-economic achievements, which - for those times - could be termed 'technological revolutions'. A number of words analyzed prove their affinities with local names, especially in mountainous areas. A careful analysis proves that indigenous people of SE Europe associated names of metals with the rocky regions where the respective metals were probably found. Another term like Gr. lébes 'cauldron' proves that cauldrons were initially made of stone, probably naturally concave stone-slabs. The evolution from a lithic to a metallic civilization is obvious.

Of course, not all the aspects connected to pre-historic metallurgy are so clear. We are sometimes forced to use our imagination in order to reconstruct a possible pre-historic tableau, e.g. the feasible hypothesis that meteoric iron was known by primitive man from immemorial times. Later man was surprised to observe that he 
himself could process and produce this metal known by his ancestors. It cannot be therefore surprising that iron was imagined imbued with magic powers.

It would be interesting to extend the investigation of metallurgical terms at a general European (or Euro-Asiatic) scale, from reconstructable pre-historic times down to present day. Such an attempt (though to a restricted scale) was recently done (Ivanov 1983, with a mis-guiding title) yet many questions remain unanswered and there still is much uncertainty in working with the pre-IE substratum. I do not see any real progress in comparative linguistics unless the pre-IE heritage becomes more coherently analyzed.

It would be also interesting to investigate the situation of metallurgical terminology in certain areas, e.g. Modern SE Europe (cf. Mihail 1981), in Romance, Germanic or Celtic languages. Basque ${ }^{5}$, Albanian ${ }^{6}$ and the Fenno-Ugric languages may also offer valuable data.

The close connection between metals, skills and the mythological representations may also be a fruitful theme. I pointed here only several essential aspects, among which is of particular importance to note the analogy of derivation of the type: mountainous area - metal/ mountainous area - god-name. Such details show that the pre-IE heritage of Europe is much more important and much more resistant than we are accustomed to consider. It must become clear that a proper analysis of the pre-IE heritage requires a change (or a radical revision) of what we know from the comparative grammar of the $\mathbb{E}$ languages. Linguists should be prepared to see and interpret complex realities otherwise. The Indo-Europeans represented only one component of European ethnogenesis and we cannot expect a real progress without taking into consideration the other essential component: the pre-IE substratum. Such a large and deep perspective cannot be practically approached without the co-operation of many linguists and without the constant comparison of linguistic and archaeological data. The metallurgical terminology is an example but must not remain the only example. Faute de mieux we must still refer to place-names in order to explain archaic realities. If this is still inevitable, we must anticipate the day when we have achieved a more coherent and ampler pre-IE glossary. I do not see possible the decipherment of Linear A or Etruscan without previously accomplishing this condition.

\section{ACKNOWLEDGEMENTS}

Many of the opinions presented here are due to the long discussions I once had with Prof. Gh. Muşu. Unfortunately, his works, and especially his essential contributions to a better understanding of the pre-Hellenic heritage, are little known. I also

5 Basque urre 'gold' and zirar 'silver' seem to be archaic indigenous terms, from which urraida 'copper' and respectively zirraida 'tin' are derived (Kretschmer 1952: 12).

6 Albanian hékur 'iron' is an interesting term, practically not clearly explained (cf. Mihail 1981: 37). A pre-IE origin of this word should not be rejected a priori. 
wish to express my gratitude to Prof. Marija Gimbutas for her constant and warmful assistance.

\section{References}

Alessio, G. 1935-1936. Le base preindoeuropee KAR(R)A/ GAR(R)A 'pietra'. I: Studi etruschi 9: 133-152; II: Studi etruschi 10: 165-189.

Alessio, G. 1955. Le lingue indoeuropee nell'ambiente mediterraneo. Bari: Adriatica

Benoist, L. 1966. Le compagnonnage et les métiers. Paris: PUF

Biek, L. and J. Bayley. 1979. Glass and other vitreous materials. World Archaeology 11,1: 1-25

Černyh, E.N. 1976. Drevnaja metalloobrabotka na jugo-zapade SSSR. Moskva: Nauka

Chantraine, P. 1968-1980. Dictionnaire étymologique de la langue grecque. Paris: Klincksieck

Collinder, B. 1957. Survey of the Uralic languages. Stockholm-Uppsala: Almqvist \& Wiksell

Collinder, B. 1958. Comparative grammar of the Uralic languages. Stockholm-Uppsala: Almqvist \& Wiksell

Comşa, E. 1987. Neoliticul de pe teritoriul României. Considerații. Bucureşti: Ed. Academiei (with an abstract in French).

Craddock, P.T. 1979. The copper alloys of the Medieval Islamic world - inheritors of the classical tradition. World Aarchaeology 11,1: 68-79.

Dečev, D. 1957. Die thrakischen Sprachreste. Wien: R.M. Rohrer

Eisenhut, W. 1974. Volcanus. Volcanal. Volcanalia. Paulys Realencyclopädie der classischen Altertumwissenschaft, Supplementband XIV, ed. by Hans Gärtner, pp. 948-962. München: Alfred Druckenmüller

Ernout, A. and A. Meillet 1959. Dictionnaire étymologique de la langue latine, 4th ed. Paris: Klincksieck

Faure, P. 1977. Viața de fiecare zi în Creta lui Minos, 1500 î.e.n. Bucureşti: Eminescu (French original: La vie quotidienne en Crète au temps de Minos, 1500 a.v. J. Christ. Librairie Hachette 1973).

Frisk, H. 1960 ff.Grieschisches etymologisches Wörterbuch. Heidelberg: Carl Winter

Garelli, P. 1963. Les assyriens en Cappadoce. Paris: Adrien Maisonneuve

Gerola, B. 1942. Substrato mediterraneo e latino. Studi etruschi 16: 345-368.

Gimbutas, M. 1973a. Old Europe, c. 7000-3500 B.C.: the earliest European civilization before the infiltration of the Indo-European peoples. Journal of Indo-European Studies 1, 1-2: 1-20. 
Gimbutas, M. 1973b. The beginning of the Bronze Age in Europe and the Indo-Europeans. Journal of Indo-European Studies 1, 3-4: 163-214

Gimbutas, M. 1979. The three waves of the Kurgan people into Old Europe, 45002500 B.C. Archives suisses d'anthropologie générale 43,2: 113-137

Gimbutas, M. 1982. Goddesses and gods of Old Europe. Myths and cult images. London: Thames and Hudson

Gimbutas, M. 1986. The religion of Old Europe and its legacy in the Bronze Age. 4th International Thracian Conference Boston 7-10 June 1984. pp. 249-285. Milan: Drăganu Foundation

Gimbutas, M. n.d. Spirituality of Old Europe. Manuscript.

Glotz, G. 1937. La civilisation égéenne. Nouvelle édition mise à jour par Ch. Picard. Paris: Albin Michel

Guyot, L. and P. Gibassier 1960. Les noms des arbres. Paris: PUF

Harva, U. 1946. Ilmarinen. Finnisch-ugrische Forschungen. 29: 89-104.

Ivanov, V.V. 1983. Istorija slavjanskih i balkanskih nazvanij metallov. Moskva: Nauka

Jovanović, B. 1971. Early copper metallurgy of the Central Balkans, in G. Novak (ed.) Actes du $8^{e}$ congrès international des sciences préhistoriques et protohistoriques, Beograd 9-15 Sept. 1971. (3 vols. 1971-1973). Bélgrade, vol. I: 131-140

Junius, M.M. 1985. Practical handbook of plant-alchemy. New York: Inner Traditions International Ltd.

Kernbach, V. 1983. Dicționar de mitologie generală. Bucureşti: Albatros

Kiss, L. 1980. Földrajzi nevek etimológiai szótára (an etymological dictionary of world place-names). Budapest: Akadémiai kiadó

Komorovský, J. 1986. Prometeus. Mytologické paralely. Bratislava: Smena

Kretschmer, P. 1952. Zu den ältesten Metallnamen. Glotta 32:1ff.

Lehmann, W.P. 1987. Linguistic and archaeological data for handbooks of protolanguages, in Skomal and Polomé (eds.) 1987: 72-87

Limet, H. 1960. Le travail du métal au pays de Sumer au temps de la III ${ }^{e}$ dynastie d'Ur. Paris: Les Belles Lettres

Malten, L. 1913. Hephaistos. Paulys Realencyclopädie der classischen Altertumswissenschaft, 8. Band, ed. by W. Kroll, pp. 311-366. Stuttgart: J.B. Metzler

Masson, E. 1967. Recherches sur les plus anciens emprunts sémitiques en grec. Paris

Masson, H. 1970. Dictionnaire initiatique. Paris: Pierre Belfond

Meillet, A. 1922. Introduction à l'étude comparative des langues indo-européennes, $5^{\mathrm{e}}$ éd. revue, corrigée et augmentée. Paris: Hachette

Meyer-Lübke, W. 1935. Romanisches etymologisches Wörterbuch, 3rd. ed. Heidelberg: Carl Winter

Mihail, Z. 1981. La terminologie de l'exploitation minière et métallurgique dans les langues du sud-est européen. Cahiers balkaniques (Paris), 2: 33-56 
Morpurgo, A. 1963. Myceneae graecitatis lexicon. Roma: Ateneo

Morris, W. (ed.). 1979. The American Heritage Dictionary of the English Language (AHD), Boston: Houghton Miffling Co.

Muşu, Gh. 1972. Din istoria formelor de cultură arhaică. Bucureşti: Editura ştiințifică şi enciclopedică

Muşu, Gh. 1981. Lumini din depărtări. Civilizații pre-hellenice şi microasiatice. Bucureşti: Editura ştiințifică şi enciclopedică

Muşu, Gh. 1982. Din mitologia tracilor. Bucureşti: Cartea românească

Muşu, Gh. n.d. Kronos sau creația, MS.

Paliga, S. 1987. Thracian terms for 'township' and 'fortress', and related place-names. World Archaeology 19, 1: 23-29

Paliga, S. 1989. Types of mazes. Linguistica (Ljubljana), 29: 57-70

Paliga, S. 1989. Old European, Pre-Indo-European, Proto-Indo-European. Archaeological Evidence and Linguistic Investigation. The Journal of Indo-European Studies 17/3-4: 309-334.

Polomé, E.C. 1987. Who are the Germanic people? in Skomal and Polomé (eds.) 1987: 216-244.

Renfrew, C. 1972. The emergence of civilisation. The Cyclades and the Aegean in the third millenium B.C. London: Methuen

Renfrew, C. 1979. Problems in European prehistory. Edinburgh: University Press

Ribezzo, F. 1950. Di quattro nuove voci mediterranee già credute celtiche. Revue internationale d'onomastique 2,1: 13-25

Rostaing, Ch. 1950. Essai sur la toponymie de la Provence. Paris: éd. d'Artrey

Rutkowski, B. 1972. Cult places in the Aegean world. Wrocław: Ossolineum (Bibliotheca antiqua X). Reprinted: 1986 - New Haven - London: Yale University Press

Skomal, S.N., E.C. Polomé (eds.) 1987. Proto-Indo-European: the archaeology of a linguistic problem. Studies in honor of Marija Gimbutas. Washington D.C.: Institute for the Study of Man

Taylor, T. 1987. Aspects of settlement diversity and its classification in southeast Europe. World Archaeology 19,1: 1-22

Trombetti, A. 1925. Saggio di antica onomastica mediterranea. Arhiv za arbanasku starinu, jezik i etnologiju 3: 1-116 (reprinted in Studi etruschi 13/ 1939: 263310).

Trombetti, A. 1927. La lingua etrusca e le lingue pre-indoeuropee del Mediterraneo. Studi etruschi 1: 213-238

Walde, A., J.B. Hofmann 1938-1954. Lateinisches etymologisches Wörterbuch, $3^{\text {rd }}$ ed. Heidelberg: Carl Winter

Winn, S.M.M. 1981. Pre-writing in southeastern Europe, the sign system of the Vinča culture, ca. 4000 B.C. Calgary: Western Publishers 


\section{Povzetek \\ KOVINE, BESEDE IN BOGOVI. ZGODNJA VEDNOST EVROPEJCEV O PRIDOBIVANJU IN PREDELOVANJU KOVIN TER ODSEV TEGA V IZRAZJU}

Raziskava se osredinja na jugovzhodno Evropo (kjer je $\mathrm{z}$ arheološkimi najdbami izkazan nastanek najbolj zgodnje evropske civilizacije, 'Stara Evropa'). Iz etimoloških razčlemb se vidi, da so pomembni metalurški izrazi, zvečine gř̌ki in latinski, a tudi drugih jezikov, predindoevropskega izvora. Verjetno so taki izrazi ostanki govorov iz casov pred šijenjem Indoevropcev v Evropo. Tudi imeni bogov Hephaestus in. Volcanus zrcalita predindoevropske bajeslovne izraze. Natančno tehtanje nekaterih izrazov odkriva razvoj od kamene do kovinske tehnologije. 